\title{
PENGEMBANGAN ARBORETUM TANAMAN TARUPREMANA UNTUK MENINGKATKAN DAYA TARIK WISATA DI DESA TARO KECAMATAN TEGALLALANG KABUPATEN GIANYAR
}

\author{
I.D.P. Singarsa ${ }^{1}$, I.K. Sardiana ${ }^{2}$, W.P. Windia ${ }^{3}$, dan K.K. Dinata ${ }^{4}$
}

\begin{abstract}
ABSTRAK
Kegiatan pengabdian kepada masyarakat ini untuk mengembangkan arboretum tanaman taru premana untuk meningkatkan daya tarik wisata Desa Taro, Kecamatan Tegallalang, Kabupaten Gianyar. Metode yang diterapkan dalam pemberdayaan masyarakat ini, diantaranya: (1) Kordinasi dan komunikasi secara partisipasif dengan kepala desa dan masyarakat desa taro untuk merumuskan program mulai dari perencanaan, operasional dan evaluasi; (2) Penyuluhan mengenai arti penting pengembangan arboretum taru premana dan kelompok sadar wisata untuk mengelola potensi kepariwisataan desa ; (3) penanaman tanaman taru premana sesuai filosofi trihita karana; (4) Pendampingan yaitu pertemuan secara berkala dan berkelanjutan antara pendamping dengan masyarakat sasaran hingga ipteks yang dialihkan dapat dilaksanakan secara mandiri oleh masyarakat. Hasil yang diperoleh menunjukkan bahwa kegiatan pengembangan arboretum tanaman tarupremana telah berjalan dengan baik. Jumlah tanaman taru premana yang dapat dikembangkan sebanyak 1000 pohon, terdiri dari 9 jenis, yaitu 400 pohon dari jenis kelapa daksina serta 600 pohon dari jenis kayu yaitu cendana, nagasari, pala, cempaka, mundeh, kwanitan, rijasa, dan majegau Masyarakat memberikan respon yang positif terhadap kegiatan pengabdian masyarakat yang dilakukan karena sesuai dengan potensi dan kebutuhan masyarakat.
\end{abstract}

Kata Kunci: arboretum, tanaman taru premana, daya tarik wisata.

\begin{abstract}
The Community service activities aimed is to develop arboretum of taru Premana plant to increase the attractiveness of tourist village of Taro, District Tegallalang, Gianyar. The method applied in this community empowerment, among others: (1) Coordination and participatory communication with village leaders and villagers taro to formulate a program from the planning, operational and evaluation; (2) Counseling on the importance of the development of the arboretum taru premana and travel awareness groups to manage the tourism potential of the village; (3) planting taru premana accordance trihita karana philosophy; (4) Assistance is meeting regularly and sustainably among companion with target communities. The results showed that the arboretum "taru premana" plant development activities have been going well. The number of plants taru Premana that can be planted as many as 1,000 trees, consists of nine types, ie 400 trees of coconut daksina and 600 trees of the wood are sandalwood, nagasari, nutmeg, cempaka, mundeh, kwanitan, Rijasa, and majegau. People respond positively to community service activities are carried out as in accordance with the potential and needs of the community.
\end{abstract}

Keywords: arboretum, taru Premana plant, tourist attraction.

\footnotetext{
1,2,4Staf Pengajar Fakultas Pertanian Universitas Udayana, ksardiana@yahoo.co.id

${ }^{3}$ Staf Pengajar Fakultas Hukum Universitas Udayana
} 


\section{PENDAHULUAN}

Desa Taro terletak di bagian utara Kabupaten Gianyar berada pada ketinggian antara 225 - 650 meter dari permukaan laut dengan luas wilayah $6,88 \mathrm{~km} 2$ terletak membujur dari arah utara ke selatan yang diapit pada sisi sebelah barat dan timur oleh Sungai Os/Wos Ulu. Suhu udara rata-rata berkisar antara $20,5^{\circ} \mathrm{C}-29,7^{\circ} \mathrm{C}$ dengan kelembaban udara antara 50 persen sampai 75 persen, pada musim hujan kelembaban dapat mencapai 89 persen menjadikan Desa Taro cukup sejuk. Rataan curah hujan masing-masing sebesar $2.700 \mathrm{~mm} / \mathrm{th}$. Landscape alam yang eksotik didukung oleh udara sejuk dan suasana pedesaan tradicional Bali yang masih alami menjadikan kawasan ini sangat diminati oleh wisatawan.

Penggunaan lahan yang dominan di wilayah Tegallalang dan Taro berupa ladang/tegalan yang mencapai 75,60 \% (1.167,55 ha), pertanian sawah 14,67 \%, penggunaan lain sebear 7,02 \%. Berdasarkan mata pencaharian, sebagian besar penduduk Desa Tegallalang dan Taro hidup dari berkebun yaitu sebanyak 1.100 orang (30.07\%), kemudian disusul pada sektor pertanian sawah sebanyak 890 orang $(24.33 \%)$. Pada sektor industri kecil dan kerajinan sebanyak 707 orang (19.33 $\%$ ), sektor peternakan sebanyak 700 orang $(19.14 \%)$, pada sektor jasa dan perdagangan sebanyak 220 orang $(6.01 \%)$ dan terendah di sektor pertambangan yaitu 41 orang $(1.12 \%)$. Angka tersebut mengindikasikan bahwa sektor pertanian merupakan bidang startegis sehingga perlu medapatkan prioritas. Usaha tani merupakan bidang usaha di hulu, diharapkan dengan berkembangnya sistem pertanian yang berwawasan agribisnis dan agrowisata dapat menstimulasi bidang jasa dan usaha lainnya di hilir.

Munculnya persoalan kewilayah terkait potensi pariwisata di kedua desa di atas disebabkan oleh keterlibatan masyarakat local dalam aktivitas pariwisata tersebut sangat terbatas. Lemahnya kemampuan sumberdaya manusia menjadi faktor penghambat yang utama.. Munculnya keinginan masyarakat untuk menghutankan kembali hutan Puakan dengan tanaman yang mendukung kegiatan ritual masyarakat Bali yang dikenal dengan Taru Pramana merupakan peluang bagi kelstarian hutan tersebut. Langkah ini dapat disertai dengan penyusunan awig-awig atau perarem (aturan adat) mengenai tatakelola hutan adat dan sapi putih. Pembentukan kelompok sadar wisata dan penyelenggaraan program vokasi bagi generasi muda dibidang kepariwisataan adalah beberapa program rintisan yang dapat dilakukan untuk meningkatkan nilai kepariwisataan wilayah.

Hal di atas mendorong pengembangan program pengembangan hutan adat taru premana untuk meningkatkan daya tarik wisata di Desa Taro, Kecamatan Tegallalang kabupaten Gianyar, dalam kegiatan Ipteks bagi Wilayah kerjasama Universitas Udayana, Dirktorat Riset dan Pengabdian Dikti, serta Pemda Kabupaten Gianyar.

\section{METODE PELAKSANAAN}

Metode yang diterapkan dalam pemberdayaan masyarakat ini, diantaranya: (1) Kordinasi dan komunikasi secara partisipasif dengan kepala desa dan masyarakat desa taro untuk merumuskan program mulai dari perencanaan, operasional dan evaluasi; (2) Penyuluhan mengenai arti penting pengembangan arboretum taru premana dan kelompok sadar wisata untuk mengelola potensi kepariwisataan desa ; (3) penanaman tanaman taru premana sesuai filosofi trihita karana; (4) Pendampingan yaitu pertemuan secara berkala dan berkelanjutan antara pendamping dengan masyarakat sasaran hingga ipteks yang dialihkan dapat dilaksanakan secara mandiri oleh masyarakat; 


\section{HASIL DAN PEMBAHASAN}

Kegiatan dimulai dengan kordinasi pelaksanaan kegiatan dengan pihak terkait yaitu Badan Pengelolaan Hidup dan Lingkungan Kabupaten Gianyar, Perbekel Desa Taro, dan Bendesa Adat Taro. Kegiatan kordinasi dilakukan untuk singkronisasi pelaksanaan kegiatan, menentukan pihakpihak yang diundang, serta teknis pelaksanaan kegiatan. Kegiatan dilakukan dalam tiga bentuk, yaitu penyuluhan tentang pengembangan arboretum taru premana, penanaman tanaman taru premana, dan pengemabngan desa adat sebagai pengelola potensi wisata desa. Kegiatan dilakukan pada tanggal 3 September 2016 bertempat di Balai banjar Patas, Desa Taro Kecamatan Tegallalang kabupaten Gianayar. Narasumber pada kegiatan ini adalah Prof. Dr. Wayan P. Windia, SH, Msi, sementara bertindak sebagai instruktur tata letak penanaman jenis-jenis tanaman taru premana dipandu oleh Dr. Ir. I Ketut Sardiana, Msi.

Taru Pramana adalah jenis-jenis tanamam yang disucikan oleh umat hindu di Bali. Jenis, kegunaan, dan kasiat tanaman ini tercantum dalam lontar yang ditulis oleh Empu Kuturan, seorang rohaniawan hindu yang datang ke Bali dari Jawa sekitar abad kesembilan. Taru pramana ini merupakan tanamam yang menjadi sarana kelengkapan ritual bagi umat Hindu di Bali dan memiliki kasiat obat, dan keberadaannya sudah mulai langka di Bali. Pada kegiatan disampaikan akan pentingnya pengembangan taru premana sebagai bentuk kearifan lokal bali dalam pelestarian flasma nuftah dan pengembangan taru premana sebagai daya tarik wisata terintegrasi dengan daya tarik wisata yang ada di Desa Taro lainnya seperti wisata kuliner dan wisata lembu putih. Dari ahli hukum adat juga disampaikan peran desa adat dalam pengelolaan pariwisata desa sehingga akrivitas bisa membawa dampak positif bagi keberlangsungan desa adat. Selain penyuluhan dan pelatihan, pada kegiatan ini juga ditanam sebanyak 400 pohon bibit kelapa daksina (upakara) disepanjang telajakan jalan desa yang diharapkan mampu meningkatkan keasrian landscape desa taro.

Penanaman tanaman taru premana dilapangan mengikuti konsep trimandala, tri hita karana dan tri angga. Konsep taman tradisional Bali di atas selanjutnya dijabarkan dalam bentuk implementasi dengan pola penanaman jenis tanaman upakara sebagai berikut:

(1) Areal Pura (parahyangan). Pura merupakan tempat suci Hindu yang keseluruahan ruangnya bernilai hubungan kepadaTuhanyang bersifat vertikal. Desain taman pura sebaiknya menggunakan konsep taman yang mengambil ajaran/nilai Ketuhanan Hindu dengan pengisian jenis tanaman uapakara saja untuk memperkuat karakter pura. Jenis-jenis yang dimaksud yaitu yang digunakan dalam upacara yadnya seperti upacara ngaben, perkawinan, kelahiran dan sebagainya. Konsep penempatan tanamandalam hirarki ruang Tri Mandala Pura bisa didasarkan pada mitologi Hindu, hirarki nilai penting tanaman upakara, tingkat energi fibrasi aura yang dimiliki dan sebagainya.

Untuk menjaga kesucian pura maka daerah sekeliling Pura dibuat jalan setapak dan dengan radius apanyengker $(5-10 \mathrm{~m})$ tidak terdapat bangunan dan radius apanimpugan $( \pm 25 \mathrm{~m})$ dijadikan ruang terbuka hijau yang ditanami tanaman upakara sehingga pada waktu pelaksanaan upacara di Pura bisa difungsikan sebagai tempat persiapan (menyiapkan sarana upacara).

\section{Utama mandala}

Utama mandala merupakan ruang yang bernilai suci meliputi jeroan pura/mrajan termasuk ruang telajakan. Telajakan merupaka ruang peralihan sebelum memasuki bagian dalam/jero.

Konsep tanaman di utama mandala diutamakan tanaman yang bagian bunga, daun, dan batangnya berfungsi sebagai sarana upakara. Keindahan dan aroma wangi bunga akan memberikan efek menentramkan bathin. Tanaman berbuah dan habitus pohon dihindari untuk ditanam pada areal ini untuk mencegah hal yang membahayakan keselamatan pengguna yang dapat merusak kesucian utama mandala. Termasuk dalam jenis tanaman yang cocok ditanam di utama mandala diantaranya: nagasari, kamajaya-kamaratih, sudamala, jepun, kwanta, delima selem, menuh, soka, cendana

\section{9 | BULETIN UDAYANA MENGABDI}


(Santalum album), kamboja (Plumeria rubra L), kembang sepatu (Hibiscus rosasinensis L), puring/mas-masan (Codiaeum sp.), kenanga (Canangium odoratum Baill.) dan lain sebagainya. Telajakan memiliki konsep sebagai ruang yang mengeliminirnilai-nilai buruk/negatif dalam diri manusia. Dengan demikian konsep tata hijau di telajakan pun hams bermakna dan bernilai filosofi yang menunjang fungsi ruang utama mandala. Telajakan sebaiknya ditanami jenis tulak, kayu sisih, wregu, blatung gada, dadap, tunjang langit. Dadap sebagai sarana dalam upacara prayascita (pembersihan). Tunjang langit bermakna hubungan vertikal manusia dengan Tuhan. Hal ini diperkuat dengan karakter pohon yang berdaun sembilan dan mengarah ke langit. Nilai sembilan dalam Hindu juga memiliki multimakna, salah satunya berkaitan dengan jumlah arah mata angin dengan dewa penjaganya/dewata nawa sanga.

\section{Madyamandala}

Merupakan bagian jaba tengah bagi pura atau bagian pekarangan/natah rumah yang berisi bangunan tinggal, dapur, kamar mandi, dan jineng. Tanaman yang cocok ditanam berasal dari jenis tanaman bunga habitus pohon (soka asti, rijasa, tigaron, jepun, sandat, gaharu, manjegaudanlainlain).

\section{Nista Mandala}

Merupakan pekarangan di areal jabaan dan teba. Pada jaba terdapat desain gapura yang bermulut kodok sebagai simbol penyambutan dengan keramahan serta keterbukaan, dan aling-aling yang bernilai untuk keamanan dan kenyamanan. Taman di nista mandala juga merupakan wajah pura mengingat letaknya di depan. Tanaman dipilih yang memiliki fungsi sebagai tanaman tabir/screen, mengingat jabaan menjadi ruang bagi publik merinstirahat sementara sebelum acara persembahyangan dilakukan atau campuran tanaman aura panas dan dingin. Tanaman dengan karakter vertikal, tajuk rapat menjadi alternatif terbaik seperti canigara, bingin, ancak, rejasa, plasa, mesui atau pangkas-pangkasan. Tanaman yang cocok ditanam di zone ini merupakan tanaman buah/daun habitus pohon.

Nista mandala berupa teba bisa dimanfaatkan dengan komposisi beragam jenis tanaman keras, tanaman bambu, perkebunan, buah-buahan dan sebagainya yang ditata sedemikian rupa dengan memadukannya dengan elemen keras sehingga menjadi taman yang indah. Beberapa jenis tanaman yang cocok ditanam di teba diantaranya jebugarum/pala, utu, durian, manggis, sentul, wani, kali asem, mundeh, badung, ceroring, kepundung, dan lain-lain. Selain itu, juga cocok dipilih jenis-jenis kelapa seperti nyuh bojog, nyuh bejulit, nyuh sudamala, nyuh udang, nyuh mulung, dan nyuh gadang.
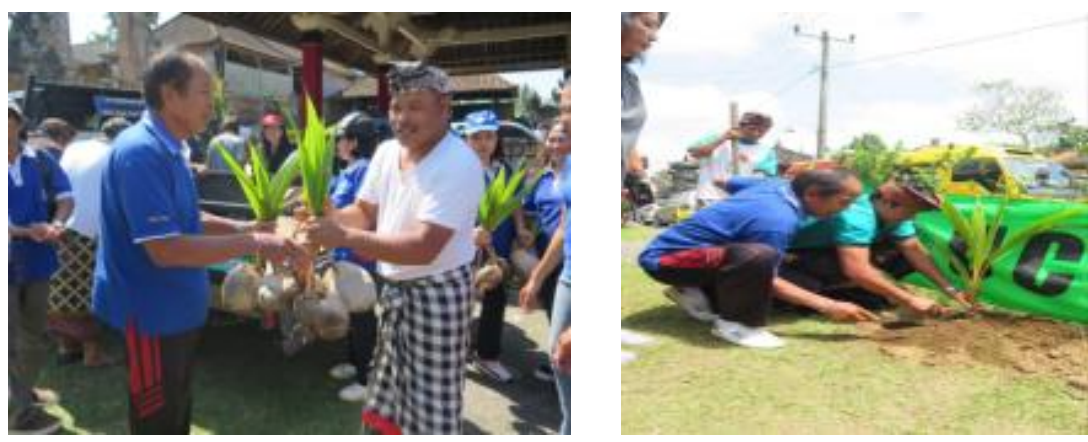

Gambar 1. Penyebarluasan dan penanaman bibit nyuh daksina di sepanjang telajakan jalan 


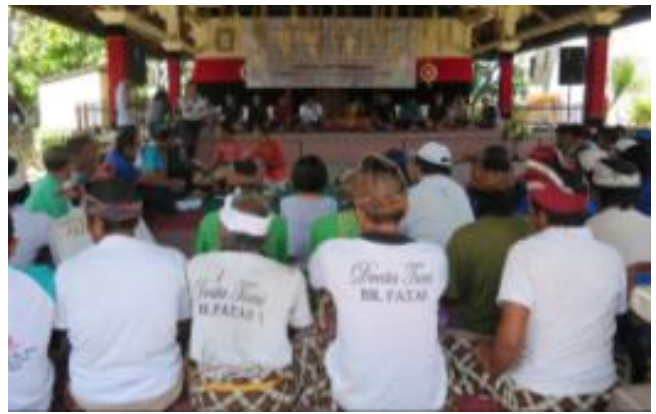

Gambar 2. Peyuluhan dan pendampingan penyusunan awig-awig (peraturan desa adat) dalam pelestarian lingkungan

Hasil kegiatan menunjukkan bahwa kegiatan penyuluhan dan penanaman bibit tanaman taru premana sudah berjalan dengan baik. Masyarakat mengikuti kegiatan dengan serius ditunjukkan oleh keatifan masyarakat dalam mengajukan persoalan terkait pengembangan arboretum tanaman upakara dan munculnya kesadaran masyarakat tentang pentingnya program tersebut terkait dengan pengembangan potensi pariwisata desa. Jumlah bibit nyuh daksina yang berhasil di tanaman sebanyak 400 pohon, sementara bibit tanaman taru premana lainnya sebanyak 600 pohon dari 8 jenis yang ditanam di sekitar lahan pelestarian lemu putih. Jenis tanaman tersebut yaitu : cendana, nagasari, pala, cempaka, mundeh, kwanitan, rijasa, dan majegau. Masyarakat memberikan respon yang sangat positif terhadap kegiatan pengabdian ini karena sesuai dengan kebutuhan dan potensi masyarakat.

\section{KESIMPULAN DAN SARAN}

Berdasarkan hasil kegiatan pengabdian kepada masyarakat rekontruksi seni tradisi bumbung gebyog dalam menunjang Desa Wisata di Desa Pinge Kecamatan marga kabupaten Pupuan dapat disimpulkan sebagai berikut:

(1) Kegiatan pengembangan arboretum tanaman tarupremana telah berjalan dengan baik.

(2) Jumlah tanaman taru premana yang dapat dikembangkan sebanyak 1000 pohon, terdiri dari 9 jenis, yaitu 400 pohon dari jenis kelapa daksina serta 600 pohon dari jenis kayu yaitu cendana, nagasari, pala, cempaka, mundeh, kwanitan, rijasa, dan majegau

(3) Masyarakat memberikan respon yang positif terhadap kegiatan pengabdian masyarakat yang dilakukan karena sesuai dengan potensi dan kebutuhan masyarakat.

\section{UCAPAN TERIMAKASIH}

Penulis menyampaikan terima kasih yang sebesar-besarnya kepada Direktorat Riset dan pengabdian Masyarakat Kemenristek Dikti atas dana yang diberikan, Ketua Lembaga Pengabdian kepada Masyarakat Universitas Udayana serta Desa Adat taro yang telah membantu kelancaran kegiatan ini

\section{DAFTAR PUSTAKA}

Anon.2012. Peraturan Bupati Gianyar Nomor 27 Tahun 2012. Rencana Kerja Pemerintah Daerah (RKPD) Kabupaten Gianyar tahun 2013. Badan Perencanaan Pembangunan Pemerintah kabupaten Gianyar.

Anon. 2011. Rencana Pembangunan jangka Menengah Daerah (RPJMD) Kabupaten Tabanan Tahun 2011 2016. Badan Perencanaan Pembangunan Pemerintah Kabupaten Gianyar.

Baiquni, M. 1999. Participatory Rural Appraisal, Metode dan Teknik Partisipasi dalam Pengembangan Perdesaan. Jogjakarta : UGM Press.

101 | BULETIN UDAYANA MENGABDI 
I.D.P. Singarsa, I.K. Sardiana, W.P. Windia, dan K.K. Dinata

Chambers, Robert. 1987 Pembangunan Desa Mulai dari Belakang. (Pepep Sudradjat, penerjemah). Jakarta : LP3ES.

Daldjoeni, N. dan A. Soeyitno. 1978. Pedesaan, Lingkungan, dan Pembangunan. Bandung : Alumni.

David, F. R. 2002. Manajemen Strategis: Konsep. (Terjemahan oleh Sindoro A.). Jakarta: PT. Ikrar Mandiri.

Korten, David C. dan Syahrir. 1988. Pembangunan Berdimensi Kerakyatan. Jakarta : Yayasan obor Indonesia. 